\title{
NATURAL HISTORY OF Ctenus medius KEYSERLING, 1891 (ARANEAE, CTENIDAE) I: OBSERVATIONS ON HABITATS AND THE DEVELOPMENT OF CHROMATIC PATTERNS
}

\author{
ALMEIDA, C. E., ${ }^{1,2}$ RAMOS, E. F., ${ }^{1,3}$ GOUVÊA, E., ${ }^{1}$ CARMO-SILVA, M. do ${ }^{1,3}$ and COSTA, \\ $\mathrm{J}^{2}$ \\ ${ }^{1}$ Departamento de Museologia, Centro Universitário de Barra Mansa, Rua Vereador Pinho de Carvalho, 267, CEP \\ 27330-550, Barra Mansa, RJ, Brazil \\ ${ }^{2}$ Núcleo de Informatização, Coleção Entomológica, Departamento de Entomologia, IOC-FIOCRUZ \\ ${ }^{3}$ Museu Nacional do Rio de Janeiro/UFRJ \\ Correspondence to: Carlos Eduardo Almeida, Departamento de Entomologia, Fundação Oswaldo Cruz, Av. Brasil, \\ 4365, CEP 21045-900, Manguinhos, Rio de Janeiro, RJ, Brasil, e-mail: calmeida@ nit.intelnet.com.br \\ Received May 5, 1998 - Accepted July 28, 1999 - Distributed August 31, 2000
}

(With 4 figures)

\begin{abstract}
Ctenus medius Keyserling, 1891 is a common species in several spots of Mata Atlântica, however there is a great lack of studies in all aspects of its natural history. This work aims to elucidate aspects of ecotope preference compared to large spiders, and to provide data on the development of chromatic patterns during its life cycle. The observations on the behavior of $C$. medius were done in the campus of Centro Universitário de Barra Mansa (UBM) by means of observations and nocturnal collections using cap lamps. For observations on the development of chromatic patterns, spiderlings raised in laboratory, hatched from an oviposition of a female from campus of UBM, and others spiderlings collected in field were used. The field observations indicate that: $C$. medius seems to prefer ecotopes characterized by dense shrub vegetation or herbal undergrowth; Lycosa erythrognatha and L. nordeskioldii seems to prefer open sites; Phoneutria nigriventer seems to prefer shrub vegetation and anthropogenic ecotopes as rubbish hills; Ancylometes sp. seems to prefer ecotopes near streams. Concerning chromatic patterns, it was observed that males and females show well distinct patterns during the last two instars, allowing distinction by sex without the use of a microscope. Through chromatic patterns it was also possible to draw a distinction between $C$. medius and $C$. ornatus longer that $3 \mathrm{~mm}$ cephalothorax width. 69 specimens of $C$. medius (males and females) collected in the campus of UBM did not show a striking polymorphism in chromatic pattern, but one among 7 adult females collected in National Park of Itatiaia, showed a distinct chromatic pattern.
\end{abstract}

Key words: Ctenus medius, Ctenidae, natural history.

\section{RESUMO}

\section{História natural de Ctenus medius Keyserling, 1891 (Araneae, Ctenidae) I: observações sobre o habitat e desenvolvimento do padrão cromático}

Ctenus medius Keyserling, 1891 é uma espécie comum em várias áreas da Mata Atlântica, contudo possui uma grande carência de estudos em todos os aspectos. Este trabalho visou elucidar aspectos da preferência por ecótopos comparada aos demais integrantes da comunidade da aracnofauna de médio a grande porte e prover dados sobre o desenvolvimento do padrão cromático durante o ciclo vital. As observações sobre o comportamento de $C$. medius foram realizadas no campus do Centro Universitário de Barra Mansa (UBM) por meio de observações e coletas noturnas, usando-se lanternas de cabeça. Para observações sobre o desenvolvimento do padrão cromático foram utilizados filhotes criados em laboratório, oriundos de uma mesma postura de uma fêmea coletada no campus do UBM, e outros coletados em campo. As observações em campo indicam que: $C$. medius parece preferir ecótopos caracterizados por vegetação herbácea densa; Lycosa erythrognata e L. nordeskioldii parecem preferir descampados; Phoneutria 
nigriventer parece preferir vegetação arbustiva e ecótopos artificiais, como entulhos; Ancylometes sp. parece preferir ecótopos próximos a córregos. Sobre o desenvolvimento cromático, foi observado que machos e fêmeas já mostram padrões bem distintos após a penúltima muda, permitindo a distinção sexual sem o uso de microscópio. Por meio do padrão cromático, também foi possível a distinção entre $C$. medius e $C$. ornatus em estádios que superam $3 \mathrm{~mm}$ de largura do cefalotórax. Os 69 exemplares de $C$. medius coletados no campus do UBM não mostraram polimorfismo marcante no padrão cromático, mas uma entre sete fêmeas adultas coletadas no National Park of Itatiaia mostrou um padrão distinto.

Palavras-chave: Ctemus medius, Ctenidae, história natural.

\section{INTRODUÇÃO}

Although the spider family Ctenidae is rich in species, little is known about its biology and ecology. In this family, the taxa most studied in their behavioral and taxonomic aspects belong to the genera Phoneutria (Simó, 1984; Simó \& Bardier, 1989; Ramos et al., 1998), Cupiennius (Melchers, 1963; Höger \& Seyfarth, 1995) and Ctenus (Höfer et al., 1994; Gasnier, 1996).

For Ctenus medius Keyserling, 1891, the description is based almost exclusively on the sexual structures of the adults (Mello-Leitão, 1936), with little reference to chromatic patterns, and there is a complete lack of studies focusing on its ecology.

Because of he lack of observations on $C$. medius in the field, we want to characterize the ecotope where this species occurs, in comparision with other members of the community of spiders ranging from medium to large sizes that co-occur with $C$. medius in the studied area.

As this species in common in several sites of Mata Atlântica, an increased knowledge of its ecology could lead to its use as an indicatory species in comparative analyses of native and disturbed ecosystems.

The description and identification of $C$. medius and most other spider species is usually done by its sexual structures, allowing only the identification of adults with the help of microscopy, not allowing its identification in field. Thus, this work was carried out with the aim to increase knowledge on the development of chromatic patterns and to infer on a possible usefulness of this feature in the sexual distinction and identification of immature spider in the field for the purpose of ecological studies.

\section{MATERIAL AND METHODS}

\section{Study area}

Barra Mansa is located in the south of Rio de Janeiro ( $\left.22^{\circ} 32^{\prime} \mathrm{S} 44^{\circ} 10^{\prime} \mathrm{W}\right)$. In general, the relief is a plateau at an altitude between 381 and 400 $\mathrm{m}$ where the Paraíba do Sul River crosses the urban area, and an average annual rain fall of $1,380 \mathrm{~mm}$ (Andrade, 1995). The animals were collected and observed in the campus of Centro Universitário de Barra Mansa (UBM), which comprehends an area of 34,900 $\mathrm{m}^{2}$ being reforested, with exotic and native species, located about $500 \mathrm{~m}$ away from the city at $50 \mathrm{~m}$ of Paraíba do Sul River up.

This environment constitutes a refuge for members of the native local fauna because the neighboring regions were deteriorated by agriculture and cattle raising. With the purpose of increasing data about the species, collections and observations were performed in the wild area of the National Park of Itatiaia ([PNI] 22²0'S 44 $\left.{ }^{\circ} 30^{\prime} \mathrm{W}\right)$. Was chosen an area with lesser natural alteration in its vegetation at about $800 \mathrm{~m}$ of altitude. According to Segadas-Vianna (1965), this area is in Mont Serrat, in the lowest level of the mountain, covered by secondary forest.

\section{Sampling method}

To infer about the habitat of $C$. medius compared to the community of spiders ranging from medium to large sizes, collections and nocturnal observations were performed with the use of cap lamps. The light emitted on the eyes of the spiders is reflected, which facilitates their location.

Daylight observations were also performed by raising up rocks, tree trunks and examining the vegetation. 


\section{Development of the chromatic pattern}

For this part of the study, spiderlings of the same offspring from campus of UBM were collected. Each spiderling was kept in an individual transparent cylindric container measuring $14 \mathrm{~cm}$ of height and $4 \mathrm{~cm}$ of diameter. The spiderlings were fed three times the weekly with a varied diet, constituting of insects and arachnids collected in campus. Water was offered in damped cotton balls. The changes of the chromatic pattern was observed through visual recording (in vivo) and photographic analyses and comparison among the different instars.

\section{RESULTS}

\section{Observations on habitats}

Through careful collection during the day, the species of medium to large spiders found in this period were the same with the help of cap lamps at night in campus of UBM.

The dominant spiders in the studied area were: C. medius, C. ornatus and Phoneutria nigriventer (Ctenidae); Ancylometes sp. (Pisauridae); Lycosa erythrognatha and L. nordeskioldii (Lycosidae).

It was observed that, even occurring in the same study area as $C$. medius and C. ornatus, spider of the family Lycosidae usually occur in two well defined ecotopes, and not further than 10 meters apart from each other. The first ecotope is an uncovered site where members of the Lycosidae family are frequent during the night, and most of the time stay in their hole during the day. The second ecotope is characterized by bushes densely planted with members of the Commelinacea family where the two species of Ctenus are found, but difficulty Lycosidae. Some young of $P$. nigriventer were also observed in this environment, but apparently they were less abundant than $C$. medius and $C$. ornatus. Ancylometes sp. occurred near a stream that crosses UBM campus.

Young and adults Lycosidae are found in every uncovered site and eventually get into the houses, whereas this fact is less common to Ctenus, except for adult males, which wander to meet females.

Food resources in the microhabitat of $C$. medius are quite diverse, but this spider seems to have a preference for other arachnidae. In captivity C. medius actively hunt Lycosidae, $C$. ornatus and even smaller individuals of its own species. During the day C. medius was found in humid places under rocks and tree trunks among bushes. At night, when they leave for hunting, they are usually found on the edge of leaves in bushes, always at a height inferior to $60 \mathrm{~cm}$ from the ground. It seems that this behavior helps in the perception of the prey through vibration of the vegetation.

In the studied area, $P$. nigriventer occupied a habitat characterized by the effect of human interference, e.g. hill-like deposits rubbish. In this anthropogenic $C$. medius was seldom found.

\section{Development of the chromatic pattern}

In the first and second instar the spiders present a grayish color without dorsal design (Fig. 1). From the third instar on they present an orange brown color. After the fifth instar the pattern is maintained and one can see a lighter line formed by hair that is stretched longitudinally over the cephalotorax (Fig. 2). The general color of the young instars is orange brown, both in the legs as on the cephalotorax and abdomen. Dorsally on the abdomen, after the sixth or seventh instar, vestiges of the pattern of the male subadult and adult were observed (in both males and females).

Before the last two moult $\mathrm{s}$ it was possible to recognize the sex of the young instars. In the males, the chromatic pattern of the dorsal part kept orange brown, but became slightly lighter, with the abdominal pattern quite visible. In the females the abdomen became black, and no pattern remained visible.

The sides of the abdomen become lighter and the legs darker. A vestige of the longitudinal line on the cephalotorax was noticed. In this stage they were in the tenth up to the twelfth instar, with a cephalotorax about $7 \mathrm{~mm}$ width.

Before the last moult in the males the abdomen became lighter, loosing the brown and gaining the orange color, showing clearer abdominal patterns, similar to those of the males before the last moult and on the cephalotorax sparse light gray hair came up, what gave this tone to the upper part of the cephalotorax. In this stage a similar design of dorsal pattern to anterior stages is more visible (Fig. 3).

For the females in this same stage, the upper part of the cephalotorax and the abdomen became almost completely black and they did not present any dorsal design (Fig. 4). 


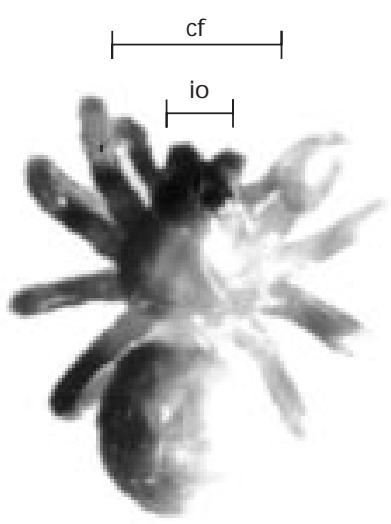

io $=0.290 \mathrm{~mm}$

cf $=0.763 \mathrm{~mm}$

Fig. 1 - Spiderling of second instar. io = width of ocular area; $\mathrm{cf}=$ width of carapace (in millimeters).

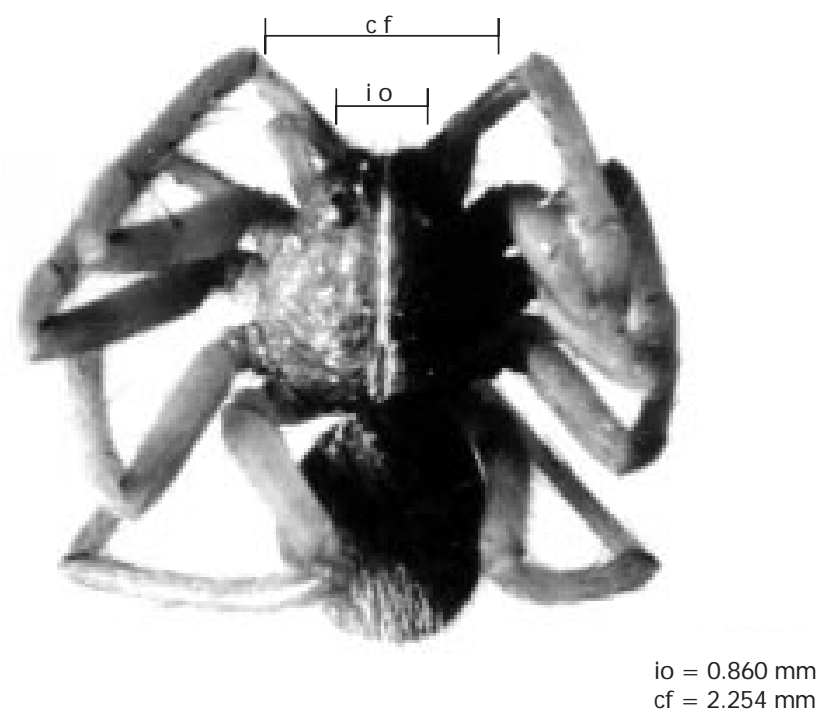

Fig. $2-$ Spiderling of sixth instar. io $=$ width of ocular area; $\mathrm{cf}=$ width of carapace (in millimeters).

In this stage it was observed that the hair was more orange on the legs of the females whereas in the males it tended to be light gray.

After the last moult in the male there was no significant change in the chromatic pattern of the cephalotorax in relation to the previous stage, but the abdomen became completely light gray with clearer design patterns and the hair of the legs became longer and the color even more light gray. As to the morphological changes the same phenomenon was observed in some other members of the genus (e.g. C. ornatus and C. amphora): increase of length size of legs in relation to the prossoma.

After the last moult, the female presented little change, keeping the black pattern. There was no morphological change noticeable at naked eye, besides the increase of size.

These patterns were consistent in two males and in one female raised in laboratory that reached sexual maturity in captivity; and also in eight males and in two females collected as subadults, in which the pattern development was watched up to adult stage. 


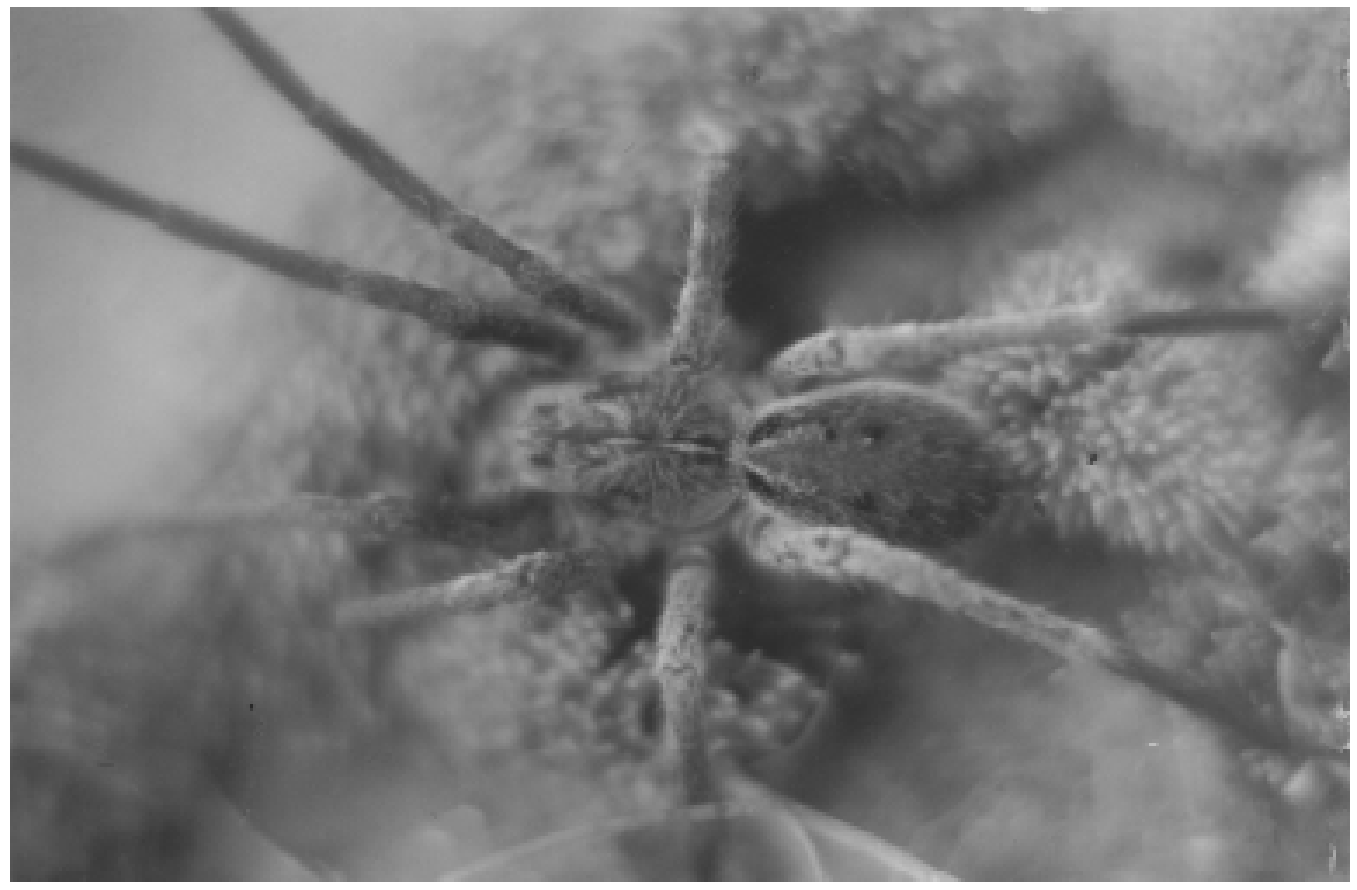

Fig. 3 - Subadult male (before the last moult).

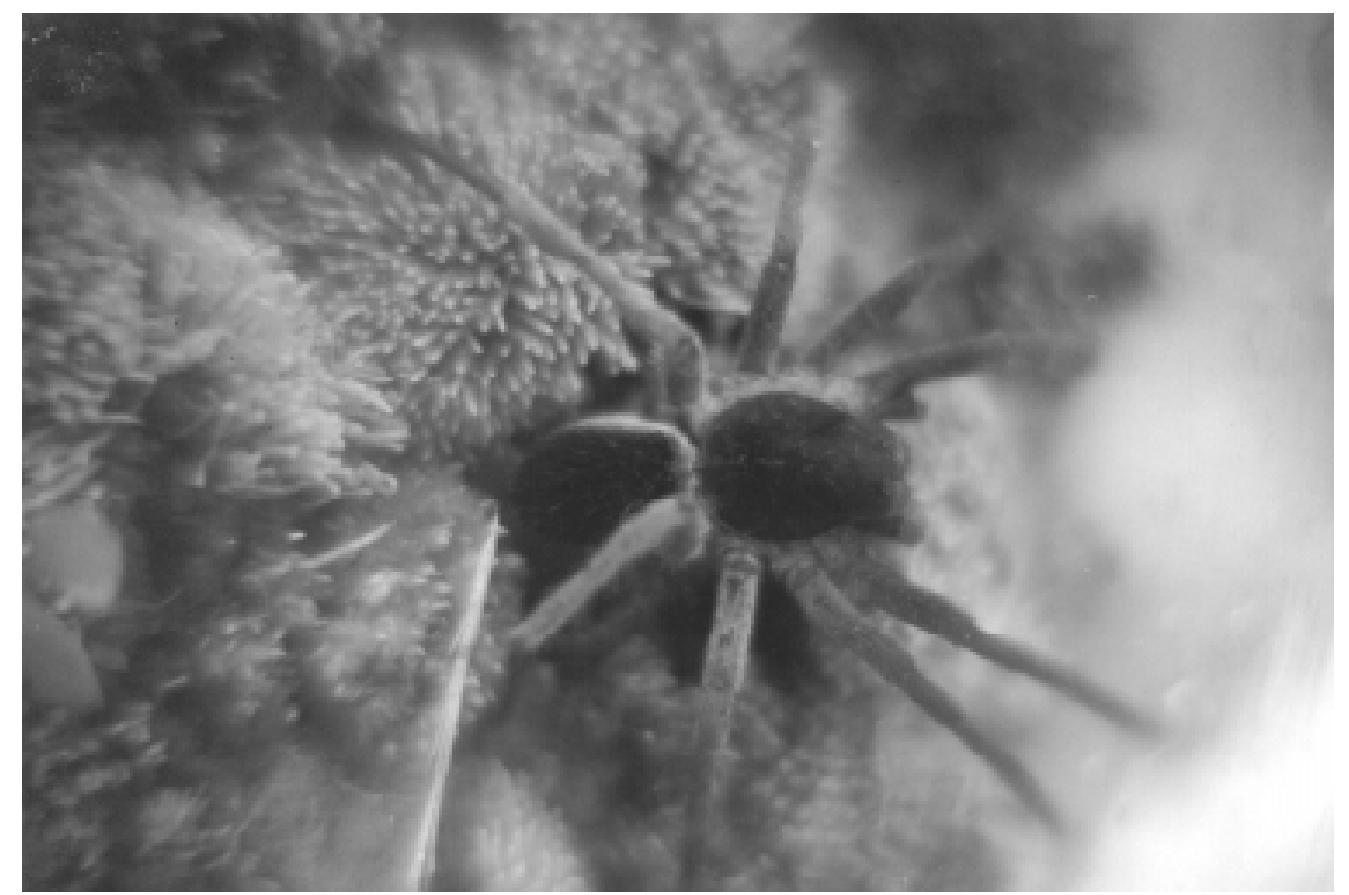

Fig. 4 - Subadult female (before the last moult). 
A female went through twelve moult and another one through thirteen until reaching sexual maturity and a male went through twelve, another one thirteen and two others fourteen to reach sexual maturity.

Sixty nine adult females with the pattern mentioned above were collected in campus of UBM. A $C$. medius female with a different chromatic pattern, presenting beige spots on cephalotorax, abdomen and legs, was collected in the National Park of Itatiaia, in the same area were six females with the pattern described above were collected.

\section{DISCUSSION}

As stated by Ramos et al. (1998), P. nigriventer is usually found in anthropogenic ecotopes in the area, whereas $C$. medius and $C$. ornatus do not are usually found in this environment, probably having preference for dense vegetation or herbal undergrowth (as Commelinaceae) where they are found at night on the ground or on low leaves in the shrubs. During the day they are found hidden under the rocks, tree trunks or other shelters, always under vegetation in humid places.

Observations and collects in field showed that the assemblage of medium to large wandering spiders in the campus of UBM occupies the following habitats: 1 . in ecotopes constituted by shrub vegetation and herbal undergrowth (as Comelinaceas) mainly $C$ medius and $C$ ornatus are found and $P$. nigriventer less usually, however these are rarely occupied by Lycosidae; 2 . in ecotopes characterized by the lack of shrub vegetation (open sites) where only very low Gramineas are common Lycosidae occurred frequently, and other taxa of the community were rarely found; 3 . in anthropogenic ecotopes, $P$. nigriventer occurred and occasionally Lycosidae, but rarely $C$. medius and C. ornatus; 4 . in ecotopes characterized by the proximity to streams Ancylometes sp. was found.

In captivity $C$. medius actively hunts Lycosidae, $C$. ornatus and even smaller individuals of its ows species. Thus we hypothetize that adult Lycosidae, which are generally smaller than $C$. medius, their behavior of not invading the ecotope where $C$. medius are frequent prevent them from being hunted.
The results of the study of the chromatic patterns show that in the studied area it is possible to separate C. medius from $C$. ornatus without visualizing the sexual structures, as well as, to perform sexual distinction in each species. The analysis of the chromatic pattern made it possible to draw a distinction between adult and immature in $C$. ornatus in the campus of UBM. $C$. ornatus shows a chromatic pattern completely distinct in the adult females and subadult males, with distinct design pattern on the top of the abdomen. In immature of $C$. medius the general color is always orange brown without a white design pattern (or yellowish) and in $C$. ornatus the general color is blackish brown with a design similar to a Greek amphora, coming close to what was illustrated in Höfer $e t$ al. (1994) for C. amphora. The only confusion that can happen is in adult males that feature similar chromatic patterns. As to sexual distinction, $C$. medius shows well defined chromatic patterns before its last two moults. From these instars on, sexual distinction is possible in the field, without the use of a microscope ( $3 \mathrm{~mm}$ width of cephalotorax).

Therefore, the technique of identification and sexual distinction by dorsal chromatic pattern may be very valuable mainly for future ecological work, where identification and sexual distinction must be done with adequate precision and rapidness in field.

According to illustrations and descriptions of $C$. villasboasi (Höfer et al., 1994), there is a similarity with the adults of $C$. medius. In females the pattern over the abdomen is not visible whereas in males the pattern is visible. The similarity is emphasized by the fact that among all species of Ctenus illustrated in Höfer et al. (1994), the design pattern over the abdomen of the subadult male of $C$. medius is more similar to the one in the adult male of $C$. villasboasi. The adult females of $C$. medius do not feature a longitudinal ventral line on the cephalotorax as the C. villasboasi.

A similarity concerning the chromatic pattern was also noticed between C. ornatus and C. amphora. Besides this similarity, Höfer et al. (1994) stated that $C$. amphora is smaller than $C$. villasboasi. It was also observed that $C$. ornatus is smaller than $C$ medius. However, for a better understanding of a possible phylogenetic meaning of these similarities, it would be necessary to increase knowledge on the other species of the 
genus, not only through taxonomic but also through biological, molecular and ecological studies.

Acknowledgments - To Centro Universitário de Barra Mansa - UBM, for supporting the research. To Dr. Antonio D. Brescovit and to Dr. Thierry Gasnier, for suggestions, for critical reading of the manuscript and for information on the Ctenus of Reserva Ducke in Manaus.

\section{REFERENCES}

ANDRADE, R., 1995, Dados gerais sobre o município de Barra Mansa. Acessoria de Pesquisa e Planejamento. 8p.

GASNIER, T. R. J., 1996, Ecologia comparada de quatro espécies de aranhas errantes do Gênero Ctenus (Walckenaer) (Araneae, Ctenidae) em uma floresta na Amazônia Central: Bases para um modelo integrado de coexistênica. Tese de Doutorado, Instituto Nacional de Pesquisa da Amazônia, Universidade do Amazonas, 77p.

HÖFER, H., BRESCOVIT, A. D. \& GASNIER, T., 1994, The wandering spider of genus Ctenus (Ctenidae, Araneae) of Reserva Ducke, a rainforest reserve in Central Amazonia. Andrias, 13: 81-98.

HÖGER, U. \& SEYFARTH, E., 1995, Just in the nick of time: postembrionic development of tactile hairs and of tactile behavior in spiders. Zoology, 99: 49-57.
MELCHERS, M., 1963, Zur Biologie und zum Verhalten vom Cupiennius salei (Keyserling), einer amerikanischen Ctenide. Zool. Jb. Syst., 91: 1-90.

MELlO-LEITÃO, C. F., 1936, Contribution a l'etude des Ctenides du Bresil. Festschr. Strand, 1: 1-31.

RAMOS, E. F., ALMEIDA, C. E., GOUVÊA, E. \& CARMOSILVA, M., 1998, Considerações sobre a atividade de locomoção, preferência por ecótopos e aspectos territoriais de Phoneutria nigriventer (Keyserling, 1891), (Araneae, Ctenidae). Rev. Brasil. Biol., 58(1): 71-78.

SEGADAS-VIANNA, F., 1965, Ecology of The Itatiaia Range, Southeastern Brazil. I- Altitudinal Zonation of the vegetation. Arquivos do Museu Nacional. Vol. LIII, pp. 1-29.

SIMÓ, M. \& BARDIER, G., 1989, Desarrolo postembrionario de Phoneutria keyserlingi (Pickard-Cambridge, 1989) (Araneae, Ctenidae). Bol. Soc. Zool. Uruguay, 5: 15-16.

SIMÓ, M., 1984, Nota breve sobre la introducción al Uruguay de la araña del banano Phoneutria nigriventer (Keyserling, 1891) Y Phoneutia keyserlingi (Pickard-Cambridge, 1897) (Araneae, Ctenidae). Aracnologia, Supl., 4: 1-4. 